\title{
THE EFFECT OF POSTPARTUM COPING SKILL CLASSES (PCSC) ON STRESS LEVEL, CORTISOL LEVELS, MATERNAL SELF- EFFICACY, AND BABY'S GROWTH AND DEVELOPMENT IN SEMARANG, CENTRAL JAVA
}

\author{
Runjati $^{1}$, Elisa Ulfiana ${ }^{2}$, Sri Wahyuni ${ }^{3}$ and Sri Rahayu ${ }^{4}$ \\ ${ }^{1}$ Poltekkes Kemenkes Semarang, Jl Tirto Agung Pedalangan Banyumanik Semarang \\ ${ }^{2}$ Poltekkes Kemenkes Semarang, Jl Tirto Agung Pedalangan Banyumanik Semarang \\ ${ }^{3}$ Poltekkes Kemenkes Semarang, Jl Tirto Agung Pedalangan Banyumanik Semarang \\ ${ }^{4}$ Poltekkes Kemenkes Semarang, Jl Tirto Agung Pedalangan Banyumanik Semarang
}

Corresponding author: Runjati

Email : runjati@yahoo.com

\begin{abstract}
Postpartum stress incidence rate is quite high (26\% - 85\%). Several studies reveal that more than $50 \%$ of women experience stress and depression after giving birth and almost $80 \%$ of new mothers experience terrible sadness feelings after giving birth, often called postpartum stress. This study aims to determine the effect of postpartum coping skill classes (PCSC) on stress level, cortisol level, maternal self-efficacy (MSE), and baby's growth and development. This study employed an experimental design method with a randomized study pre-test post-test control group design. The study was conducted on 18 postpartum women who were given PCSC treatment which was integrated into postpartum classes and 17 women were given postpartum classes $(P C)$ only. The study was conducted in 4 weeks. The data were analyzed statistically using a t-test method. Ethical clearance for the study was obtained. The results disclose that PCSC significantly decrease the PSS score $(-2.66 \pm 4.74, p=0,029)$. Similarly, the cortisol level drops significantly $(-38.53 \pm 74.60, p=$ 0.031). In other respect, the MSE score between groups have significant mean difference $(p=0.013)$, but the weight gain and development of the baby between the two groups have no significant mean difference ( $p$ $>0.05$ ). The provision of coping skill classes through maternal classes for postpartum women was effective in decreasing stress levels, cortisol levels, and increasing MSE scores although it did not affect the baby's growth and development.
\end{abstract}

Keywords: postpartum coping skill classes, Maternal self-efficacy, cortisol, stress levels, baby's growth, and development

\section{INTRODUCTION}

The postpartum period is a period after giving birth and may last for 4 to 6 weeks during which time the mother begins to possess more confidence to provide care for her baby. Psychological, social, and physical factors take essential factors for this process. Women will experience some episodes of the vulnerable situation and must face tremendous challenges to finally make their transition to becoming a mother. ${ }^{1}$ Postpartum stress incidence is quite high reaching $26 \%$ $85 \%$. Some studies describe that more than $50 \%$ of women experience stress and depression after childbirth and almost $80 \%$ of new mothers experience feelings of sadness after childbirth or often called postpartum stress. ${ }^{2}$ There are about $50-70 \%$ of all postpartum women will experience this syndrome. Meanwhile, in Indonesia, around $50-70 \%$ of women experience this syndrome and continue to postpartum depression with the incidence varies from $5 \%$ to more than $25 \%$ after the childbirth. ${ }^{2}$

Currently, maternal and child health counseling is still generally performed through individual consultation or case by case method that is given during postnatal care or at the time of Posyandu (Integrated Care unit in community) activities. Such counseling activities are beneficial for the management of the case by case. However, to make it easier for postpartum women to understand the contents of $\mathrm{MCH}$ book and how to use $\mathrm{MCH}$ book, education in the form of classes for postpartum women and the under-five children mothers are planned. The planned education is a systematically integrated system which can be carried out on a regular and continuous basis using a face-to-face format followed by discussions between mothers and the healthcare provider. The education classes are called 
"Postpartum Women Class and Under-five Children Mothers Class". ${ }^{3}$

A study of combining health education and coping skills was performed in antenatal classes assessing the perceived stress and childbirth self-efficacy. The study showed improvement after intervention in these aspects. ${ }^{4}$ Other studies, particularly postpartum mothers do not integrate the under-five children mothers' activities with maternal coping skills that would enable mothers not only to get benefits from the practice of postpartum care and infant care but also to improve the mother's emotional aspects of stress after childbirth process and during the postpartum period. A mother's ability to cope with stress during the postpartum period is a significant factor for the postpartum mother to access help during the postpartum period. ${ }^{5}$ This study aims to determine the effect of postpartum coping skill classes on stress level, cortisol level, maternal self-efficacy (MSE), and baby's growth and development.

\section{METHODOLOGY}

\section{Study Design and Sampling Procedure}

The study was an experimental design with a randomized study pre-test post-test control group design. ${ }^{6}$ The samples were collected by using a cluster random sampling technique in fourth public health centers in Semarang from 37 public health centers that meet the criteria. The Fourth public health centers were selected randomly to be as a control group and as an experimental group. The samples from each public health center then also were randomly selected. In this study, 36 respondents were consisting of postpartum women in the first week - 6th week of the postpartum period. There was nine respondent for each the health public center that has been chosen randomly. In the experimental group, there were 18 respondents, and 18 others were assigned to the control group. that was selected randomly to be as an experimental group and as a control group. While the subject in the control group, there was one mother drop out because she could not complete all the process.

The study is conducted by providing treatment using postpartum coping skill classes (PCSC) method to reduce stress and cortisol levels, increase maternal selfefficacy (MSE) as well as the baby's growth and development. There were fourth classes and each class was consist of 9 mothers. The class was given by midwives as a facilitator. The class was done each week for four weeks The experiment group in this study was given the PCSC while the control group was given standard postpartum classes (PC). The dependent variable is stress, cortisol levels, maternal self-efficacy (MSE), and growth and development of the baby.

\section{Instrument Development and Data Collection Procedure}

The study instrument for the control group is postpartum classes (PC) modules as standard operating procedures developed by the Ministry of Health. PC was done through postpartum women classes to prepare mothers for the postpartum period and child care. While postpartum coping skill classes (PCSC) intervention employed PC standard and educational methods of Coping Skill training (CST) namely postpartum coping skill classes (PCSC) to help mothers cope with stress during the postpartum and to prepare the mothers to be parents. Coping skill modules were develop based on initial research namely antenatal coping skill classes that were reviewed by expert. ${ }^{4}$ Data were taken from the mothers in the first week and the fourth-week postpartum period, and then the women were treated for the first week, the second week, and the third week. In each week, one class of the control group was given PC and one class of experimental groups was given PCSC.

Stress levels were measured using perceived stress scale (PSS), ${ }^{7}$ mother's belief to be parents was measured using maternal selfefficacy (MSE), $, 8,9$ and the growth and development of baby were measured using anthropometry and development prescreening questioner (DPSQ). ${ }^{10,11}$ Variables stress level, cortisol level, MSE, and baby's growth and development were measured in the first week before the intervention and the fourth week after intervention. The level of cortisol was taken from the blood vessel and measured using the ELISA method.

\section{Ethical Considerations}

Ethical clearance was proved by the ethical committee of Health Polytechnic of Semarang number 367KEPK/Poltekkes-SMG/EC/2017. All participants worked voluntarily in which the informed consent was given before the study began. 
Data Processing and Analysis

This study used a different difference test of the T-test to analyze data. This test was used to determine the difference in mean values between the interconnected groups. A paired T-test was used to compare the mean values of before and after treatment. Before processing, the normality of the data was tested first by using the Shapiro Wilk test that had been corrected with Liliefors by looking at $t \mathrm{p}$ value. ${ }^{12}$

\section{RESULTS}

\section{a. Socio-demographic characteristics}

The characteristic of the mother is shown in table 1 . Test the difference in the two groups using the Mann-Whitney $U$ test obtained value $p>0.05$ in age, parity (number of children), employment, education, and support. Based on the aforesaid statistics, we conclude that there is no difference in age, gestational age, support, employment, and education in the two groups. Also, the data characteristics of the respondents in the two groups are homogeneous.

Table 1: Characteristics of mother

\begin{tabular}{|c|c|c|c|}
\hline & PCSC $(\mathrm{N}=18)$ & $\mathrm{PC}(\mathrm{N}=18)$ & \\
\hline Characteristics & $\begin{array}{c}\text { Median } \\
\text { (min - maks) } \\
\mathrm{n}(\%)\end{array}$ & $\begin{array}{c}\text { Median } \\
\text { (min -maks) } \\
\mathrm{n}(\%)\end{array}$ & $p$ \\
\hline Age & $25(20-33)$ & $24(20-33)$ & $0.532^{*}$ \\
\hline $20-25$ & $10(55)$ & $11(61)$ & \\
\hline $26-30$ & $5(28)$ & $4(22)$ & \\
\hline $31-35$ & $3(17)$ & $3(17)$ & \\
\hline Paritas & & & $0.712^{*}$ \\
\hline Primi & $15(83)$ & $16(89)$ & \\
\hline Multi & $3(17)$ & $2(11)$ & \\
\hline Education & & & $0.352^{*}$ \\
\hline Primary & $3(17)$ & $2(11)$ & \\
\hline Secondary & $10(55)$ & $9(50)$ & \\
\hline Tertiary & $5(28)$ & 7 (39) & \\
\hline Occupation & & & $0.813^{*}$ \\
\hline Housewife & $11(61)$ & $12(66)$ & \\
\hline Private & $6(33)$ & $5(28)$ & \\
\hline Teacher & $1(6)$ & $1(6)$ & \\
\hline Support & $10(9-10)$ & $10(9-10)$ & $0.187^{*}$ \\
\hline
\end{tabular}

${ }^{*}$ Mann Whitney $U$ test

\section{b. Stress Level}

Table 2. shows the p-value of the PSS score of the different tests before and after Postpartum coping skill training classes intervention with paired t-test in the experiment group $(<0.05)$. In other words, there is a significant difference in the mean of PSS score before (19.38) and after (16.72) intervention of Postpartum coping skill training classes with a decrease of -2.66 and standard deviation of 4.74 .

In the control group, the PSS score of the different tests before and after Postpartum coping skill classes intervention with paired $\mathrm{t}$ test shows $p$-value $=0.536$. So, there is no significant difference in the mean of PSS score before (19.35) and after (18.64) intervention of Postpartum coping skill training classes with the decrease of -0.71 and standard deviation of 4.60 .

Further, the difference between the two groups is tested based on the mean difference in each group using the MannWhitney test. Difference test results show $p>$ 0.05 meaning that there is no significant difference in the mean difference of PSS scores between the experimental group and the control group. The experiment group shows a decreased mean of PSS score that of -2.66 with a standard deviation of 4.74 , while the control group showed a decreased mean of -0.71 with a standard deviation of 4.60 . 
Table 2: Differences in PSS scores pre and post-intervention by group

\begin{tabular}{|c|c|c|c|}
\hline Group & $\begin{array}{l}\text { Pre } \\
\text { mean } \pm \text { SD }\end{array}$ & $\begin{array}{l}\text { Post } \\
\text { mean } \pm \text { SD }\end{array}$ & $p$ \\
\hline PCSC & $19.38 \pm 5.52$ & $16.72 \pm 6.16$ & $0.029^{f}$ \\
\hline $\begin{array}{l}\text { PC } \\
\triangle \text { PSS Score } \\
\text { PCSC } \\
\text { PC }\end{array}$ & $\begin{array}{r}19.35 \pm 4,24 \\
-2.66 \pm 4.74 \\
-0.71 \pm 4.60\end{array}$ & $18.64 \pm 4.93$ & $0.536^{\ngtr}$ \\
\hline
\end{tabular}

\section{c. Cortisol levels}

Table 3 discloses the differences in serum cortisol levels before and after intervention by the group. In the experimental group, the difference in cortisol levels before and after Postpartum coping skill training classes intervention is analyzed using a Wilcoxon test that obtains a $p$-value of $<0.05$. This value suggests that there is a significant difference in the mean of cortisol levels before (138.74) and after (100.21) Postpartum coping skill training classes intervention. The mean change of cortisol levels is -38.53 with a standard deviation of 74.6.
In the control group, the difference in cortisol levels before and after PC is analyzed using the Wilcoxon test and obtained $\mathrm{p}=0.84$. In other words, there is no difference for the cortisol levels in the control group before and after PC, although there is a change in the mean of cortisol levels of - 30.53 with a standard deviation of 64.8.

The difference test result of cortisol levels changes between-group show that there is no significant difference in cortisol levels $(p=0.74)$ in the experiment group that received $P C S C$ intervention and in the control group that received $\mathrm{PC}$.

Table 3. Differences in serum cortisol levels before and after intervention by a group

\begin{tabular}{|c|c|c|c|}
\hline \multirow[t]{2}{*}{ Serum cortisol levels } & Pre & Post & \multirow[t]{2}{*}{$p^{¥}$} \\
\hline & mean \pm SD & $\begin{array}{l}\text { mean } \pm S \\
D\end{array}$ & \\
\hline PCSC & $138.74 \pm 12.59$ & $\begin{array}{l}100.21 \pm \\
10.40\end{array}$ & $\begin{array}{l}0.03 \\
1\end{array}$ \\
\hline PC & $130.15 \pm 10.86$ & $\begin{array}{l}99.63 \pm \\
6.97\end{array}$ & 0.84 \\
\hline $\begin{array}{l}\Delta \text { Cortisol } \\
\text { PCSC } \\
\text { PC }\end{array}$ & $\begin{array}{l}-38.53 \pm 74.6 \\
-30.52 \pm 64.8\end{array}$ & & $\begin{array}{l}0.74 \\
*\end{array}$ \\
\hline
\end{tabular}

${ }^{7}$ pre vs post: Wilcoxon, *Independent $t$-test

\section{d. MSE Score}

Table 4 depicts the difference in MSE scores before and after intervention by the group. In the experiment group, MSE score difference before and after Postpartum coping skill classes intervention is analyzed using the Wilcoxon test which then obtains the $p$-value of $>0.05$. This value suggests that there is no significant difference in the mean of MSE scores before and after Postpartum coping skill classes (PCSC) intervention. In the control group, MSE scores before and after PC is analyzed using paired t-test and obtain the $\mathrm{p}$-value of $>0.05$, meaning that there is no difference in MSE score in the control group before and after PC.

The difference test result of the mean MSE score between groups shows that there is a significant difference in MSE score $(p=0.013)$ in the experiment group that receive $\mathrm{PCSC}$ and in the control group that receives $\mathrm{PC}$. 
Table 4: The difference in MSE scores before and after intervention by a group

\begin{tabular}{llll}
\hline MSE Score & Pre & Post & $P$ \\
\cline { 2 - 3 } & mean \pm SD & mean \pm SD & \\
\hline PCSC & $31.17 \pm 3.60$ & $32.11 \pm 4.25$ & $0.282^{*}$ \\
PC & $34.00 \pm 3.60$ & $33.47 \pm 3.59$ & $0.237^{\sharp}$ \\
$\Delta$ MSE Score & & & \\
PCSC & $0.94 \pm 3.60$ & & $0.013^{* *}$ \\
PC & $-0.52 \pm 1.90$ & & \\
\hline Y & r & &
\end{tabular}

$¥$ pre vs post: Wilcoxon, ${ }^{*}$ Paired $t$-test, ${ }^{* *} \mid n d e p e n d e n t ~ t$-test

\section{e. Baby's Growth and Development}

Tables 5 and Table 6 elucidate the baby's weight in the experimental and control groups. The mean changes for the experimental and control groups which receive Postpartum coping skill training classes (PCSC) and PC interventions are equally increased, and each group also shows a significant difference in BW before and after the intervention. However, the difference in the BW test in both groups shows no significant difference with the $p$ value $=0.219$. Meanwhile, the development indicators measured by the development prescreening questioner (DPSQ) score also show different results suggesting that there is no significant difference with $p>0.05$ in the change of DPSQ score before and after PCSC and $P C$ in both groups. On the other side, the difference test of the DPSQ score between the two groups shows no significant difference with the $p$-value $=0.636$.

Table 5. Differences of Baby's Weight before and after intervention by a group

\begin{tabular}{llll}
\hline BW & Pre & Post & $P$ \\
\cline { 2 - 3 } & mean \pm SD & mean \pm SD & \\
\hline PCSC & $3530.00 \pm 621.3$ & $3871.47 \pm 891.06$ & $0.00^{*}$ \\
PC & $4098.23 \pm 868.65$ & $4520.00 \pm 226.18$ & $0.00^{7}$ \\
$\Delta$ BW & & & \\
PCSC & $352.11 \pm 328,031$ & & $0.219^{* *}$ \\
PC & $421.76 \pm 231,09$ & & \\
\hline
\end{tabular}

$¥$ pre vs post: paired $t$-test, ${ }^{*}$ Wilcoxon, ${ }^{* *}$ Mann Whitney

Table 6. The difference in DPSQ scores before and after intervention by a group

\begin{tabular}{llll}
\hline DPSQ Score & Pre & Post & $P$ \\
\cline { 2 - 3 } & mean \pm SD & mean \pm SD & $0.282^{*}$ \\
\hline PCSC & $6.0 \pm 1.83$ & $7.9 \pm 1.34$ & $0.237^{*}$ \\
PC & $5.29 \pm 1.79$ & $6.82 \pm 1.5$ & \\
$\Delta$ DPSQ & & & $0.636^{* *}$ \\
PCSC & $1.94 \pm 1.66$ & & \\
PC & $1.52 \pm 1.12$ & &
\end{tabular}

\section{DISCUSSION}

The study result shows that PCSC intervention was significantly in decreasing perceived stress for the postpartum mother compared to PC. Postpartum women who received PCSC treatment were more able to understand stress and danger in the postpartum period. Besides, they also understand better how to deal with stress and more skillful in facing and reducing stress. The study result is in line with the other study which provided cognitive behavior interventions in pregnancy period showing the differences in perceived stress among pregnant mothers who received the intervention.13 Another study was also done by different researchers. They gave cognitive behavior intervention during pregnancy which the result showed that there is the same condition during the postpartum period. Those aforesaid studies prove that mastering coping skills to reduce stress during the postpartum period is essentially needed by the mother. 
In this study, the coping skill material was given simultaneously with postpartum classes which showing the beneficial effects for the mothers to cope with stress during the postpartum period. The provision of PCSC materials helps the mothers employ their stress-coping skills and ability through problem-focused coping and emotionalfocused coping in stabilizing the mothers' psychological condition during the postpartum period. PCSC helps the mothers apply their ability to perceive problems positively and overcome negative emotions. ${ }^{14}$

In other respect, postpartum mothers were also trained PCSC involving maternal cognitive and behavioral processes to cope with stress during the postpartum period. This training allowed the mothers to perceive stress positively and to manage certain behaviors to cope with stress, to manage hard situations positively, and to apply their ability in employing resources to reduce stress. Coping skills help postpartum mothers to manage stress well. ${ }^{15}$

The provision of postpartum coping skill training classes can minimize the psychological and physiological effects of stress. In other words, the administration of Postpartum coping skill training classes has a positive impact on the neuro-hormonal arrangements in postpartum women which influence the results of the postpartum outcome. ${ }^{16}$

The study result shows that both groups have a significant decrease in cortisol levels, but the decrease of cortisol levels in the experiment group that received PCSC intervention is greater than the control group that received PC. The level of cortisol in postpartum women is influenced by the role of the HPA axis in responding to the stress, corticotrophin in releasing hormone (CRH) that regulates $\mathrm{ACTH}$ secretion from the pituitary and as feedback from synthesis and cortisol release. ${ }^{17}$

The intervention of postpartum coping skill training classes proven as an effective way to reduce the stress levels of postpartum mothers. The classes play an important role in decreasing the levels of postpartum women's cortisol. The stress levels decrease as the HPA axis and the neuroendocrine system respond to the excessive production of cortisol. ${ }^{17}$
The material which is delivered through PCSC reinforces the mothers' ability and skills in coping with any intervention types. The mothers can change the source of stress to be a challenge and to restore the homeostatic body in such circumstances. Besides, the mothers are able to change the state of stress into eustress that benefits them to achieve the satisfaction and well-being during the childbirth period including pregnancy, labor, and postpartum which potentially make the mothers experience changing cortisol level.18 Pregnant mothers experience a high level of cortisol due to pregnancy until labor and then in the postpartum period mother experience drawl of cortisol until 4 days of the postpartum period. The changes in cortisol levels are strongly related to emotional problems during the postpartum period. However, this result is still controversial. ${ }^{19}$

Regarding MSE, the study reveals that the provision of postpartum coping skill training classes (PCSC) intervention is able to increase the MSE score compared to the provision of postpartum classes (PC) although the difference in the increase is not quite significant. Furthermore, the study result proves that postpartum women who received PCSC intervention and receive the material at the same time can practice the coping strategy skillfully such as problem-focused coping (PFC) and emotion-focused coping (EFC) strategies which are useful for mothers to increase their self-confidence and ability to perform certain activities in facing postpartum period. The study also discloses that even during postpartum, postpartum mothers mostly apply EFC rather than PFC. ${ }^{20}$ The exercises given to postpartum mothers through CST intervention is EFC exercise through a self-affirmation or selfstrengthening technique. Self-affirmation exercises help the mothers relieve their tension and increase their confidence to perform specific acts ${ }^{21}$ related to Postpartum coping skill training classes intervention. PCSC intervention through PFC training in the form of problem-prioritizing and problemsolving skills help the mothers improve their skills in identifying stress sources and also managing problems as stress sources that help them to reduce stress. ${ }^{22}$ Meanwhile, the postpartum mothers who receive $P C$ do not get the PFC and EFC material and exercises.

The study result proves that postpartum women who receive PCSC intervention obtain the material and, at the same time, they can practice coping strategies such as PFC and 
EFC which are useful for them to increase their self-confidence, and ability to perform a certain action to face postpartum period. MSE is a crucial factor for facilitating mothers during the motherhood period. PCSC intervention contains both EFC and PFC skills that provide proper coping response capability for the mothers. Coping response capability can protect mothers and infants from the dangers of stress response. ${ }^{23}$ It will also help the mothers understand better the implementation of EFC and PFC and is expected to help improve maternal selfefficacy of postpartum women.

The further hypothesis is that Postpartum coping skill training classes further improve the growth of postpartum mothers' infants compared to MATERNAL CLASSES is not accepted. Growth and development are illustrated by infant weight (BW) gain and the progression which are measured through a pre-screening development questionnaire (KPSP). Infant growth is influenced by various factors especially in the early growing period such as nutrition sufficiency from the mother in the form of exclusive breastfeeding. Fulfillment of nutrition requirement factor from exclusive breastfeeding or others is not assessed in this study. Similarly, the developmental factors - which are supposed to be assessed based on the KPSP, the influence of the nutrients, and also the stimulation from the mother - are not assessed in this study.

\section{CONCLUSIONS}

PCSC intervention was able to decrease the stress level of postpartum women that was characterized by the decrease of PSS score before and after the intervention, and the decrease in cortisol level before and after the intervention. PCSC intervention was able to enhance the MSE that was characterized by the increase of MSES score. PCSC intervention does not affect infant growth compared to PC

\section{ACKNOWLEDGMENTS}

The author would like to thank the Health Polytechnic of Semarang for technical and funding supports. Also, many thanks to all participants and midwives which helped facilitate this study.

\section{REFERENCES}

1. Bobak LP. Maternity and Women Health.; 2008.
2. Kasdu D. Operasi Caesar Masalah Dan Solusinya. Jakarta: Puspa Swara. Jakarta: Puspa Swara; 2013.

3. Kemenkes RI. Pedoman Pelaksanaan Kelas Ibu Hamil.; 2011. doi:351.077 Ind $\mathrm{r}$

4. Runjati, Susanto H, Sawitri DR, Thaufik S. The effect of antenatal class plus coping skill training on the level of stress and childbirth selfefficacy. Adv Sci Lett. 2017;23(4):3329-3333. doi:10.1166/asl.2017.9125

5. Bilszta J, Heidelberg V, Ericksen J, Buist A, Milgrom J. Women's experience of postnatal depression beliefs and attitudes as barriers to care. Ajan. 2010;27(3):44. http: / /www.ajan.com.au/Vol27/AJAN _27-3.pdf\#page=45.

6. Creswell JW. Research Design, Qualitative, Quantitative, Dan Mixed Methods Approaches, Third Edition. California: SAGE Publications; 2009.

7. Witt, W; Litzelman, K; Cheng, E.R; Wakeel, F; Barker E. Measuring stress before and during pregnancy: A review of Population-based studies of Obstetric outcomes. NIH Public Access. 2013;18(9):1199-1216. doi:10.1016/j.micinf.2011.07.011.Inna te

8. Bandura A. Self-Efficacy in Changing Societies. Cambridge University Press; 2009.

9. Leahy-warren P, Mccarthy G, Corcoran P. First-time mothers: social support , maternal parental self-efficacy and postnatal depression. 2011. doi:10.1111/j.1365-2702.2011.03701.x

10. Kementerian Kesehatan RI. Buku Kesehatan Ibu Dan Anak. (Kementerian Kesehatan RI, ed.).; 2015.

11. Kementerian Kesehatan RI. Pedoman Pelaksanaan Stimulasi, Deteksi Dan Intervensi Dini Tumbuh Kembang Anak Di Tingkat Pelayanan Kesehatan Dasar. (Kemenkes Ri, ed.).; 2012.

12. Dahlan S M. Statistik Untuk Kedokteran Dan Kesehatan. 6th ed. Jakarta: 
Salemba medika; 2014.

13. Khorsandi $M$, Vakilian $K$, Salehi $B$, Goudarzi MT, Abdi M. The effects of stress inoculation training on perceived stress in pregnant women. J Health 2015. doi: $10.1177 / 1359105315589800$

14. Guardino CM SC. Coping during pregnancy: a systematic review and recommendations. Health Psychol. 2015;8(1):70-94.

15. Taylor SE. Health Psychology. Vol 53. New York: Mc Graw-Hill Education; 2015.

16. Meltzer-Brody S. New insights into perinatal depression: pathogenesis and treatment during pregnancy and postpartum. In: LLS SAS; 2011:333341.

17. Seaward B. Physiology of Stres. Manag Stress. 2012:34-48.

18. Zelena D. The janus face of stress on reproduction: From health to disease. Int J Endocrinol. 2015;2015. doi:10.1155/2015/458129

19. De Rezende MG, Garcia-Leal C, De Figueiredo FP, et al. Altered functioning of the HPA axis in depressed postpartum women. J Affect Disord. 2016;193:249-256. doi:10.1016/j.jad.2015.12.065

20. Norliza J, Siti Khuzaimah A, Emad A, Norimah S. Depression and Coping Strategies Used by Postnatal Mothers During the Postpartum Period. MJP Online Early. 2014;11(2).

21. Myers DG. Social Psychology. 2010

22. Lazarus RS FS. Stress, Appraisal, and Coping. Vol 23. New York: spinger Publishing Company, Inc; 1984.

23. Shorey S, Chan SWC, Chong YS, He HG. Predictors of Maternal Parental SelfEfficacy Among Primiparas in the Early Postnatal Period. West J Nurs Res. 2015;37(12):1604-1622. doi:10.1177/0193945914537724 